\title{
The Use of Trastuzumab in Metastatic Breast Cancer Shawky El-Hadad ${ }^{1}$, Hassan Khalid ${ }^{2}$, Ahmed El-Agamawi ${ }^{2}$, Mohsen Salah El-Dien Zekry ${ }^{2}$, Hanan El-Shahat El-Morsi ${ }^{2 *}$ \\ Clinical Oncology Department, ${ }^{1}$ Cairo University, ${ }^{2}$ Al-Azhar University
}

Corresponding author: Hanan El-Shahat El-Morsi, Mobile; (+20) 01092983129, E-mail: tantawy_wael@yahoo.com

\begin{abstract}
Background: Breast cancer is the most common malignancy in women in US and the second cause of cancer death. It comprises $14 \%$ of all new cancers, and $6.8 \%$ of all cancers deaths.

Objectives: To evaluate the value of targeted therapy (trastuzumab) in HER-2 positive metastatic breast cancer patients previously treated with anthracycline in the adjuvant setting, in terms of related toxicities, objective response, overall survival, and progression free survival.

Patients and Methods: This study included 80 patients with history of primary carcinoma of the breast with HER2neu positive and evidence of metastases. Half the cases received a combination of trastuzumab plus paclitaxel aiming to treat their disease compared with other group, which received paclitaxel alone to asses the effect of trastuzumab.

Results: Adding trastuzumab to paclitaxel showed significant positive impact on treatment, objective response, progression-free survival (PFS) and overall survival (OS). In the attempt to evaluate the variable prognostic importance, such as positive family history, performance status, disease grade and tumor size all showed significant impact on objective response, PFS and OS.

Conclusion: The metastatic form of the breast cancer is of dismal prognosis. Targeted therapy created a new avenue in the management of this grim disease. This study show that adding trastuzumab to paclitaxel had significantly improved the objective response, PFS and OS.
\end{abstract}

Keywords: Trastuzumab, Metastatic Breast Cancer.

\section{INTRODUCTION}

Breast cancer is the most common malignancy in women in US and the second cause of cancer death. It comprises $14 \%$ of all new cancers, and $6.8 \%$ of all cancers deaths ${ }^{(1)}$. The estimated metastatic breast cancer is at least 154,000 patients in US, among them $6 \%$ are de novo ${ }^{(2)}$.

Commonly metastases arise months or years after the patient has completed treatment for early or locally advanced breast cancer.

The risk of metastatic breast cancer varies according to:

(1) The biology of the tumor.

(2) The stage at the time of original diagnosis.

(3) The treatment for the original cancer ${ }^{(3)}$

Chemotherapy is the first line of treatment for metastatic breast cancer that are:

(1) Hormone receptor negative

(2) Hormone receptor positive but no longer respond to hormone therapy.

(3) HER-2 negative and HER-2neu positive in combination with anti HER-2 treatment ${ }^{(3)}$

Metastatic breast cancer (MBC) is an incurable disease, and systemic treatment aims to prolong survival, control disease progression, control symptoms, and enhance patient quality of life ${ }^{(4)}$.

The human epidermal growth factor receptor 2 (HER-2, HER-2neu, c-erbB-2) gene. It is localized to chromosome $17 \mathrm{q}$ and encodes a transmembrane tyrosine kinase receptor protein that is a member of the epidermal growth factor receptor (EGFR) or HER family. The overexpression or HER-2 or its amplification occurs in $15 \%-20 \%$ of invasive breast cancers. HER-2 has been validated as a prognostic factor and also as predictive biomarker for HER-2 targeting therapy. Metastatic patients with HER-2 positive tumors are known to have aggressive disease and poor prognosis, with shorter overall survival (OS) and disease free survival time ${ }^{(5)}$.

Receptor activation requires three variables, a ligand, a receptor, and a dimerization partner. After a ligand bind to a receptor, it interact with another receptor of identical or related structure in a process known as dimerization in order to trigger phosphorylation and activate signaling cascades. This process is associated with increased cell proliferation, cell motility tumor invasiveness, progression regional and distant metastasis, accelerated angiogenesis, and reduce apoptosis ${ }^{(\boldsymbol{)})}$.

The use of taxanes in treating breast cancer has been growing exponentially since the mid -1990s. Anthracycline and taxanes based treatment regimens are standard first line therapies for MBC. The goals of treatment in MBC include prolonged survival, symptoms control and maintenance of quality of life (7). Paclitaxel is among the most active chemotherapy for treatment of patients with advanced breast cancer $(\mathrm{ABC})$, and metastatic breast cancer (MBC) following anthracycline-containing chemotherapy ${ }^{(8)}$.

\section{AIM OF THE WORK}

To evaluate the value of targeted therapy (trastuzumab) in HER-2 positive metastatic breast cancer patients previously treated with anthracycline in the adjuvant setting, in terms of related toxicities, objective response, overall survival, and progression free survival. 


\section{PATIENTS AND METHODS}

This study included 80 patients with history of primary carcinoma of the breast with HER2neu positive and evidence of metastases.

Half the cases received a combination of trastuzumab plus paclitaxel aiming to treat their disease compared with other group who received paclitaxel alone to asses the effect of trastuzumab.

\section{Patients Selection:}

- Age : range from 30 - 80 years

- Patients were diagnosed as having metastatic breast cancer after more than 6 months of their primary tumor

- Pathology documented over expression or amplification of HER2 neu

- Eastern Co operative Oncology Group performance ECOG status $<3$

- White blood cells > 4000/ $\mathrm{mm}^{3}$, platelets counts $>100000 / \mathrm{mm}^{3}$ and hemoglobin $>9$ $\mathrm{g} / \mathrm{dL}$

- Adequate renal and liver functions

- Measurable disease can be assessed either clinically or radiologically.

\section{Exclusion criteria:}

- Cardiac patients with ejection fraction $(\mathrm{LVEF}<50 \%$ )

- Autoimmune disease

- Other malignancy of the skin (Basel cell carcinoma)

\section{Patients:}

Base line evaluation include

- Proper history especially drug intake as anticoagulant

- Clinical examination

- Assessment of performance status

- Complete biological and hematological tests

- Chest X ray or CT

- Pelvi abdominal US or CT

- Echo

- Bone isotopic scan

- Documentation of hormonal status and HER2neu

- Documentation of adjuvant therapy

Ethical approval and written informed consent:

- An approval of the study was obtained from Al- Azhar University academic and ethical committee. Every patient signed an informed written consent for acceptance of the operation.

\section{ASSESMENT OF TOXICITY}

Toxicity was evaluated with each cycle according to The National Cancer Institute (NCI) Common Toxicity Criteria ${ }^{(9)}$.

Disease evaluation: the objective response, PFS and OS.

\section{Treatment strategy:}

- All patients who fulfill the eligibility criteria received trastuzumab in initial dose $8 \mathrm{mg} / \mathrm{kg}$ then maintenance dose $6 \mathrm{mg} / \mathrm{kg}$ every three weeks was administrated intravenously over 90 minutes with paclitaxel $175 \mathrm{mg} / \mathrm{m}^{2}$ administrated intravenously over 3 hours compared with other group of patients received paclitaxel alone with the same criteria

- Prior of each cycle:

All patients were assessed with complete blood count, biochemical tests and echo every 3 months.

All patients underwent evaluation of primary response after 3 cycles of the therapy clinically and radiologically. Patients who showed complete response, partial response, or stable disease continued in our study then followed up after further 3 cycles of the treatment.

\section{Statistical analysis}

Recorded data were analyzed using the statistical package for social sciences, version 20.0 (SPSS Inc., Chicago, Illinois, USA). Quantitative data were expressed as mean \pm standard deviation (SD). Qualitative data were expressed as frequency and percentage.

\section{The following tests were done:}

- Independent-samples t-test of significance was used when comparing between two means.

- Chi-square $\left(\mathrm{x}^{2}\right)$ test of significance was used in order to compare proportions between two qualitative parameters.

- The confidence interval was set to $95 \%$ and the margin of error accepted was set to $5 \%$. The $\mathrm{p}$ value was considered significant as the following:

- Probability (P-value)

- P-value $<0.05$ was considered significant.

- P-value <0.001 was considered as highly significant.

- P-value >0.05 was considered insignificant. 
RESULTS

Table (1): Clinico-epidemiological characteristics

\begin{tabular}{|c|c|c|c|c|c|c|c|}
\hline & \multicolumn{2}{|c|}{$\begin{array}{c}\text { Group I } \\
\text { "Trastuzumab plus } \\
\text { Paclitaxel" } \\
\text { "n=40" }\end{array}$} & \multicolumn{2}{|c|}{$\begin{array}{c}\text { Group II } \\
\text { "Paclitaxel alone" } \\
\text { "n=40" }\end{array}$} & \multicolumn{2}{|c|}{ Total } & \multirow[t]{2}{*}{$P$ value } \\
\hline & No. & $\%$ & No. & $\%$ & No. & $\%$ & \\
\hline $\begin{array}{l}\text { Age } \\
<50 \\
>50\end{array}$ & $\begin{array}{l}26 \\
14\end{array}$ & $\begin{array}{l}65.0 \\
35.0\end{array}$ & $\begin{array}{l}24 \\
16\end{array}$ & $\begin{array}{l}60.0 \\
40.0\end{array}$ & $\begin{array}{l}50 \\
30\end{array}$ & $\begin{array}{l}62.5 \\
37.5\end{array}$ & $>0.05$ \\
\hline $\begin{array}{l}\text { Range } \\
\text { Mean } \\
\text { S.D. } \\
\text { Median }\end{array}$ & \multicolumn{2}{|c|}{$\begin{array}{c}30-60 \\
44.6 \\
9.6 \\
44.0 \\
\end{array}$} & \multicolumn{2}{|c|}{$\begin{array}{c}31-59 \\
46.5 \\
8.9 \\
45.0 \\
\end{array}$} & \multicolumn{2}{|c|}{$\begin{array}{c}30-60 \\
45.8 \\
9.5 \\
45 \\
\end{array}$} & $>0.05$ \\
\hline $\begin{array}{l}\text { Menopausal status } \\
\text { Pre menopausal } \\
\text { Post menopausal }\end{array}$ & $\begin{array}{l}27 \\
13\end{array}$ & $\begin{array}{l}67.5 \\
32.5\end{array}$ & $\begin{array}{l}26 \\
14 \\
\end{array}$ & $\begin{array}{l}65.0 \\
35.0 \\
\end{array}$ & $\begin{array}{l}53 \\
27 \\
\end{array}$ & $\begin{array}{l}66.3 \\
33.7 \\
\end{array}$ & $>0.05$ \\
\hline Positive family history & 23 & 57.5 & 19 & 47.5 & 42 & 52.5 & $>0.05$ \\
\hline $\begin{array}{l}\text { Performance status } \\
0 \\
1 \\
2\end{array}$ & $\begin{array}{c}28 \\
10 \\
2\end{array}$ & $\begin{array}{c}70.0 \\
25.0 \\
5.0\end{array}$ & $\begin{array}{r}27 \\
9 \\
4\end{array}$ & $\begin{array}{l}67.5 \\
22.5 \\
10.0\end{array}$ & $\begin{array}{c}55 \\
19 \\
6\end{array}$ & $\begin{array}{c}68.8 \\
23.8 \\
7.5\end{array}$ & $>0.05$ \\
\hline \multicolumn{8}{|l|}{ CEA } \\
\hline Normal & 21 & 52.5 & 20 & 50.0 & 41 & 51.3 & \multirow[b]{2}{*}{$>0.05$} \\
\hline Elevated & 19 & 47.5 & 20 & 50.0 & 39 & 48.8 & \\
\hline \multicolumn{8}{|l|}{ CA 15.3} \\
\hline Normal & 23 & 57.5 & 26 & 65.0 & 49 & 61.3 & \multirow{2}{*}{$>0.05$} \\
\hline Elevated & 17 & 42.5 & 14 & 35.0 & 31 & 38.8 & \\
\hline
\end{tabular}

Table (2): Comparison between the two studied groups regarding previous operation.

\begin{tabular}{|l|c|c|c|c|c|}
\hline \multirow{2}{*}{} & \multicolumn{2}{|c|}{$\begin{array}{c}\text { Group I } \\
\text { "Trastuzumab plus Paclitaxel" } \\
\text { "n=40" }\end{array}$} & \multicolumn{2}{c|}{$\begin{array}{c}\text { Group II } \\
\text { "Paclitaxel alone" } \\
\text { "n=40" }\end{array}$} & \multirow{2}{*}{ P value } \\
\cline { 2 - 5 } & No. & \% & No. & \% & \\
\cline { 2 - 5 } Type of previous operation & 18 & 45.0 & 20 & 50.0 & \\
Right MRM & 16 & 40.0 & 15 & 37.5 & \\
Left MRM & 6 & 15.0 & 5 & 12.5 & $>0.05$ \\
CBS+AL ND & 6 & 5 &
\end{tabular}

Table (2) shows the comparison between the two studied groups regarding previous operation, the majority of the patients in the two groups had MRM (45.0\% and 50.0), followed by left MRM (40.0 and 37.5\%), the CBS and AL ND was done in 6 cases in group I and 5 cases in group II, there was no significant difference between the two groups regarding type of previous operation.

Table (3): Comparison between the two studied groups regarding the ER, PR.

\begin{tabular}{|c|c|c|c|c|c|}
\hline & "Trastu & axel" "n=40" & "Pacl & " $\mathrm{n}=\mathbf{4 0}$ " & p-value \\
\hline & No. & $\%$ & No. & $\%$ & \\
\hline $\begin{array}{l}\text { ER } \\
\text {-ve } \\
+ \text { +ve }\end{array}$ & $\begin{array}{l}20 \\
20\end{array}$ & $\begin{array}{l}50.0 \\
50.0\end{array}$ & $\begin{array}{l}11 \\
29\end{array}$ & $\begin{array}{l}27.5 \\
72.5\end{array}$ & $0.039 *$ \\
\hline $\begin{array}{c}\mathbf{P R} \\
\text {-ve } \\
+\mathrm{ve}\end{array}$ & $\begin{array}{l}27 \\
13\end{array}$ & $\begin{array}{l}67.5 \\
32.5\end{array}$ & $\begin{array}{l}15 \\
25\end{array}$ & $\begin{array}{l}37.5 \\
62.5\end{array}$ & $0.007 *$ \\
\hline
\end{tabular}

Table (3) shows the comparison between the two studied groups regarding the ER, PR, the positive cases in group I regarding ER and PR was 50.0\% and 32.5 respectively, while in group II was positive ER and PR in $72.5 \%$ and $62.5 \%$, there was a significant increase in ER and PR positive cases in group II more than group I ( $<<0.05$ ). 
ejhm.journals.ekb.eg

Table (4): Comparison between the two studied groups regarding response of treatment.

\begin{tabular}{|c|c|c|c|c|c|}
\hline \multirow{2}{*}{ Response of treatment } & \multicolumn{2}{|c|}{$\begin{array}{c}\text { Group I- "Trastuzumab plus } \\
\text { Paclitaxel" "n=40" }\end{array}$} & \multicolumn{2}{|c|}{$\begin{array}{c}\text { Group II } \\
\text { "Paclitaxel alone" "n=40" }\end{array}$} & \multirow[t]{2}{*}{$P$ value } \\
\hline & \begin{tabular}{|l} 
No. \\
\end{tabular} & $\%$ & No. & $\%$ & \\
\hline Complete response & 6 & 15.0 & 1 & 2.5 & \multirow{4}{*}{$0.0012^{*}$} \\
\hline Partial response & 26 & 65.0 & 14 & 35.0 & \\
\hline Stable & 3 & 7.5 & 4 & 10.0 & \\
\hline Progressive disease & 5 & 12.5 & 21 & 52.5 & \\
\hline
\end{tabular}

Table (4) shows the comparison between the two studied groups regarding response of treatment, in group I, $80.0 \%$ of the patients showed a complete or partial response, while $7.5 \%$ stable and $12.5 \%$ progressive disease. In group II $37.5 \%$ only showed complete or partial response, $10.0 \%$ was stable, and $52.5 \%$ progressive disease. There was a significant increase in the response in group I more than group II $(\mathrm{p}<0.01)$

Table (5): Comparison between the two studied groups regarding overall survival.

\begin{tabular}{|c|c|c|c|c|c|}
\hline \multirow[t]{2}{*}{ Overall survival at end of follow up } & \multicolumn{2}{|c|}{$\begin{array}{c}\text { Group I } \\
\text { “Trastuzumab plus Paclitaxel" } \\
\text { "n=40" }\end{array}$} & \multicolumn{2}{|c|}{$\begin{array}{c}\text { Group II } \\
\text { "Paclitaxel alone" } \\
\text { "n=40" }\end{array}$} & \multirow[t]{2}{*}{$P$ value } \\
\hline & No. & $\%$ & No. & $\%$ & \\
\hline 1,2 years over all survival & 37 & 92.5 & 29 & 72.5 & $0.021 *$ \\
\hline $\begin{array}{l}\text { Mean } \pm \text { S.D. } \\
\text { Median }\end{array}$ & \multicolumn{2}{|c|}{$\begin{array}{c}18.2 \pm 5.6 \\
18.0\end{array}$} & \multicolumn{2}{|c|}{$\begin{array}{c}15.2 \pm 3.98 \\
15.0\end{array}$} & \\
\hline
\end{tabular}

Table (5), shows the comparison between the two studied groups regarding overall survival, in group I, $92.5 \%$ survived after 2 years of follow up, the mean survival time was 18.2 months, while in group II, $72.5 \%$ survived at end of follow up, the mean survival was 15.2 months, there was a significant increase in overall survival in group I more than group II ( $\mathrm{p}<0.05)$.

Table (6): Comparison between the two studied groups regarding progression free survival.

\begin{tabular}{|c|c|c|c|c|c|}
\hline \multirow[t]{2}{*}{$\begin{array}{l}\text { Progression free survival at end of } \\
\text { follow up }\end{array}$} & \multicolumn{2}{|c|}{$\begin{array}{c}\text { Group I } \\
\text { “Trastuzumab plus Paclitaxel" } \\
\text { "n=40" }\end{array}$} & \multicolumn{2}{|c|}{$\begin{array}{c}\text { Group II } \\
\text { "Paclitaxel alone" } \\
\text { "n=40" }\end{array}$} & \multirow[t]{2}{*}{$P$ value } \\
\hline & No. & $\%$ & No. & $\%$ & \\
\hline 1,2 disease free survive & 22 & 55.0 & 8 & 20.0 & \\
\hline $\begin{array}{l}\text { Mean } \pm \text { S.D. } \\
\text { Median }\end{array}$ & \multicolumn{2}{|c|}{$\begin{array}{c}12.5 \pm 6.58 \\
12.0\end{array}$} & \multicolumn{2}{|c|}{$\begin{array}{c}9.5 \pm 5.1 \\
9.0\end{array}$} & $0.0001 *$ \\
\hline
\end{tabular}

Table (6) shows the comparison between the two studied groups regarding disease free survival, in group I, $55.0 \%$ was free survive after 2 years of follow up, the mean disease free survival time was 12.5 months, while in group II, $20.0 \%$ was disease free survive at end of follow up, the mean survival was 9.5 months, there was a significant increase in disease free survive in group I more than group II $(\mathrm{p}<0.05)$.

Table (7): Comparison between the two studied groups regarding hematological toxicity.

\begin{tabular}{|c|c|c|c|c|c|c|}
\hline & \multirow[t]{2}{*}{$\begin{array}{l}\text { Hematologic } \\
\text { toxicity }\end{array}$} & \multicolumn{2}{|c|}{$\begin{array}{c}\text { Group I } \\
\text { "Trastuzumab plus } \\
\text { Paclitaxel" "n=40" }\end{array}$} & \multicolumn{2}{|c|}{$\begin{array}{l}\text { Group II } \\
\text { "Paclitaxel alone" “n=40" }\end{array}$} & \multirow[t]{2}{*}{$P$ value } \\
\hline & & No. & $\%$ & No. & $\%$ & \\
\hline Anemia & $\begin{array}{l}\text { Grade I/II } \\
\text { Grade III/IV }\end{array}$ & $\begin{array}{l}10 \\
18\end{array}$ & $\begin{array}{l}25.0 \\
45.0\end{array}$ & $\begin{array}{l}16 \\
21\end{array}$ & $\begin{array}{l}40.0 \\
52.5\end{array}$ & $0.012 *$ \\
\hline Thrombocytopenia & $\begin{array}{l}\text { Grade I/II } \\
\text { Grade III/IV }\end{array}$ & $\begin{array}{l}6 \\
7\end{array}$ & $\begin{array}{l}15.0 \\
17.5\end{array}$ & $\begin{array}{l}10 \\
13\end{array}$ & $\begin{array}{l}25.0 \\
32.5\end{array}$ & $0.0036^{*}$ \\
\hline Neutropenia & $\begin{array}{l}\text { Grade I/II } \\
\text { Grade III/IV }\end{array}$ & $\begin{array}{l}3 \\
4 \\
\end{array}$ & $\begin{array}{c}7.5 \\
10.0 \\
\end{array}$ & $\begin{array}{l}5 \\
3 \\
\end{array}$ & $\begin{array}{l}12.5 \\
7.5 \\
\end{array}$ & $>0.05$ \\
\hline $\begin{array}{l}\text { Febrile } \\
\text { neutropenia }\end{array}$ & $\begin{array}{l}\text { Grade I/II } \\
\text { Grade III/IV }\end{array}$ & $\begin{array}{l}2 \\
1\end{array}$ & $\begin{array}{l}5.0 \\
2.5\end{array}$ & $\begin{array}{l}4 \\
2\end{array}$ & $\begin{array}{l}10.0 \\
5.0\end{array}$ & $>0.05$ \\
\hline
\end{tabular}

Table (7) shows the comparison between the two studied groups regarding hematological toxicity. The anemia was significantly higher in group II more than group I, the thrombocytopenia was significantly higher in group II more than group I, while neutropenia and febrile neutropenia showed insignificant difference between the two groups. 
ejhm.journals.ekb.eg

Table (8): Comparison between the two studied groups regarding non-hematological toxicity.

\begin{tabular}{|c|c|c|c|c|c|}
\hline \multirow[t]{2}{*}{ Non-Hematologic toxicity } & \multicolumn{2}{|c|}{$\begin{array}{c}\text { Group I } \\
\text { "Trastuzumab plus Paclitaxel" } \\
\text { "n=40" }\end{array}$} & \multicolumn{2}{|c|}{$\begin{array}{l}\text { Group II } \\
\text { "Paclitaxel alone" } \\
\text { "n=40" }\end{array}$} & \multirow[t]{2}{*}{$P$ value } \\
\hline & No. & $\%$ & No. & $\%$ & \\
\hline $\begin{array}{l}\text { Nausea } \\
\text { Grade I/II } \\
\text { Grade III/IV }\end{array}$ & $\begin{array}{c}9 \\
10\end{array}$ & $\begin{array}{l}22.5 \\
25.0\end{array}$ & $\begin{array}{l}10 \\
11\end{array}$ & $\begin{array}{l}25.0 \\
27.5\end{array}$ & $>0.05$ \\
\hline $\begin{array}{l}\text { Vomiting } \\
\text { Grade I/II } \\
\text { Grade III/IV }\end{array}$ & $\begin{array}{l}10 \\
12\end{array}$ & $\begin{array}{l}25.0 \\
30.0\end{array}$ & $\begin{array}{l}13 \\
10\end{array}$ & $\begin{array}{l}32.5 \\
25.0\end{array}$ & $>0.05$ \\
\hline $\begin{array}{l}\text { Diarrhea } \\
\text { Grade I/II } \\
\text { Grade III/IV }\end{array}$ & $\begin{array}{l}5 \\
6\end{array}$ & $\begin{array}{l}12.5 \\
15.0\end{array}$ & $\begin{array}{c}10 \\
8\end{array}$ & $\begin{array}{l}25.0 \\
20.0\end{array}$ & $0.012 *$ \\
\hline $\begin{array}{l}\text { Stomatitis } \\
\text { Grade I/II } \\
\text { Grade III/IV } \\
\end{array}$ & $\begin{array}{c}10 \\
8\end{array}$ & $\begin{array}{l}25.0 \\
20.0\end{array}$ & $\begin{array}{l}19 \\
10\end{array}$ & $\begin{array}{l}47.5 \\
25.0\end{array}$ & $0.003 *$ \\
\hline $\begin{array}{l}\text { Alopecia } \\
\text { Grade I/II } \\
\text { Grade III/IV }\end{array}$ & $\begin{array}{l}2 \\
5\end{array}$ & $\begin{array}{c}5.0 \\
12.5\end{array}$ & $\begin{array}{l}10 \\
11\end{array}$ & $\begin{array}{l}25.0 \\
27.5\end{array}$ & $>0.05$ \\
\hline $\begin{array}{l}\text { Cardiac toxicity } \\
\text { Grade I/II } \\
\text { Grade III/IV }\end{array}$ & $\begin{array}{l}3 \\
2\end{array}$ & $\begin{array}{l}7.5 \\
5.0\end{array}$ & $\begin{array}{l}5 \\
6\end{array}$ & $\begin{array}{l}12.5 \\
15.0\end{array}$ & $>0.05$ \\
\hline
\end{tabular}

Table (8) shows the comparison between the two studied groups regarding non-hematological toxicity. Nausea and vomiting showed insignificant difference between the two groups, while diarrhea and stomatitis showed a significant increase in group II more than group I. Alopecia and cardiac toxicity showed insignificant difference between the two groups.

\section{DISCUSSION}

Breast cancer is the most common malignancy in women in US and second cause of cancer death. It comprises $14 \%$ of all new cancers, and $6.8 \%$ of all cancers deaths ${ }^{(\mathbf{1})}$.

The estimated metastatic breast cancer is at least 154,000 patients in The United States. Among them $6 \%$ are de novo ${ }^{(2)}$.

Commonly metastases arise months or years after the patient has completed treatment for early or locally advanced breast cancer.

The overexpression or HER-2 or its amplification occurs in 15\%-20\% of invasive breast cancers. HER-2 has been validated as a prognostic factor and also as predictive biomarker for HER-2 targeting therapy. Metastatic patients with HER-2 positive tumors are known to have aggressive disease and poor prognosis, with shorter overall survival (OS) and disease free survival time ${ }^{(5)}$.

Paclitaxel is among the most active chemotherapy in the treatment of patients with advanced breast cancer (ABC), even on those who demonstrated disease progression following anthracycline -containing chemotherapy ${ }^{\left({ }^{(8)}\right.}$.

To evaluate the value of targeted therapy (trastuzumab) in HER-2 positive metastatic breast cancer patients previously treated with anthracycline in the adjuvant setting, in terms of related toxicities, objective response, overall survival, and progression free survival.
Adding trastuzumab an paclitaxel has shown significance positive impact on treatment, objective response DFS, OS with comparable in treatment related acute toxicities.

In the attempt to evaluate the variable prognostic importance, each positive family history, performance status, disease grade and tumor size all showed significant impact on objective response DFS and OS.

\section{CONCLUSION}

The metastatic form of the breast cancer is of dismal prognosis. Targeted therapy created a new avenue in the management of this disease grim. This study show that adding trastuzumab to paclitaxel had significantly improved objective response, PFS and OS. It has been standard of care for using trastuzumab combined chemotherapy in first line treatment of metastatic breast cancer.

\section{REFERENCES}

1. David C, Paoletti C, Gersch C et al. (2016): ESR1 mutations in circulating plasma tumor DNA from metastatic breast cancer patients. Clinical Cancer Research, 22(4):993-9.

2. Alan CS, Winer EP, Goldhirsch A et al. (2015): Tailoring therapies-improving the management of early breast cancer: St Gallen International Expert Consensus on the Primary Therapy of Early Breast Cancer 2015. Annals of Oncology,26(8):1533-46. 


$$
\text { ejhm.journals.ekb.eg }
$$

3. Gelmon KA, Boyle FM, Kaufman B et al. (2014): Lapatinib or trastuzumab plus taxane therapy for human epidermal growth factor receptor 2-positive advanced breast cancer: final results of NCIC CTG MA. 31. J Clin Oncol., 33(14):1574-83.

4. Dawood S, Broglio K, Buzdar AU et al. (2010): Prognosis of women with metastatic breast cancer by HER2 status and trastuzumab treatment: an institutional-based review. Journal of Clinical Oncology, 28(1):92.

5. Mass RD, Press MF, Anderson S et al. (2005): Evaluation of clinical outcomes according to HER2 detection by fluorescence in situ hybridization in women with metastatic breast cancer treated with trastuzumab. Clinical Breast Cancer, 6(3):240-6.
6. Perou CM, Sørlie T, Eisen MB et al. (2000): Molecular portraits of human breast tumours. Nature, 406(6797):747.

7. Giordano SH, Kuo YF, Freeman JL et al. (2005): Risk of cardiac death after adjuvant radiotherapy for breast cancer. Journal of the National Cancer Institute, 97(6):419-24.

8. Fountzilas G, Tsavdaridis D, Kalogera-Fountzila A et al. (2001): Weekly paclitaxel as first-line chemotherapy and trastuzumab in patients with advanced breast cancer. Annals of Oncology, 12(11):1545-51.

9. Murty VV, Nichols G, De Castro K et al. (2002): Therapy-related myelodysplastic syndrome after autologous stem cell transplantation for breast cancer. Leukemia, 